\title{
Nuclear magnetic resonance, vibrational spectroscopic studies, physico-chemical properties and computational calculations on (nitrophenyl) octahydroquinolindiones by DFT method
}

\author{
M.A. Pasha ${ }^{\mathrm{a}, *}$, Aisha Siddekha ${ }^{\mathrm{a}, \mathrm{b}}$, Soni Mishra ${ }^{\mathrm{c}}$, Sadeq Hamood Saleh Azzam ${ }^{\mathrm{a}}$, S. Umapathy ${ }^{\mathrm{c}}$ \\ ${ }^{a}$ Department of Studies in Chemistry, Central College Campus, Bangalore University, Bangalore 560001, India \\ ${ }^{\mathrm{b}}$ Department of Chemistry, Smt. VHD Central Institute of Home Science, Bangalore 560001, India \\ ${ }^{\mathrm{c}}$ Department of Inorganic and Physical Chemistry, Indian Institute of Science, Bangalore 560012, India
}

\section{H I G H L I G H T S}

- The theoretical calculations were made using 6-311++G (d,p) method.

- Experimental IR and Raman spectra are in agreement with the theoretical results.

- Complete wave number assignments are performed on the basis of PED. - Isotropic chemical shifts for ${ }^{1} \mathrm{H}$ and

${ }^{13} \mathrm{C}$ NMR were calculated using GIAO

- Molecular electrostatic potential and thermodynamic functions have been investigated.

\section{G R A P H I C A L A B S T R A C T}

Comparison of the 2'-nitrophenyl and 3'-nitrophenyl isomers of octahydroquinolindiones.

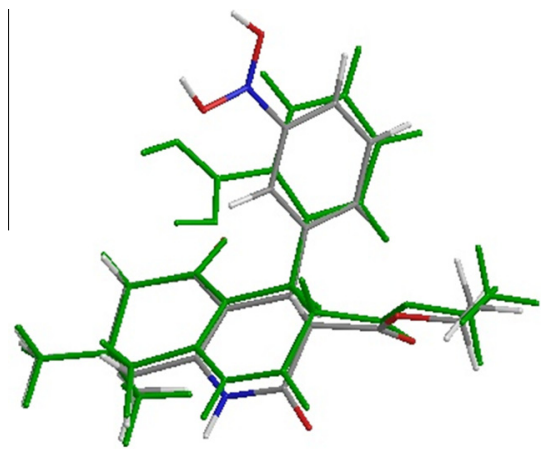

\begin{abstract}
A B S T R A C T
In the present study, $2^{\prime}$-nitrophenyloctahydroquinolinedione and its $3^{\prime}$-nitrophenyl isomer were synthesized and characterized by FT-IR, FT-Raman, ${ }^{1} \mathrm{H}$ NMR and ${ }^{13} \mathrm{C}$ NMR spectroscopy. The molecular geometry, vibrational frequencies, ${ }^{1} \mathrm{H}$ and ${ }^{13} \mathrm{C}$ NMR chemical shift values of the synthesized compounds in the ground state have been calculated by using the density functional theory (DFT) method with the 6$311++G(d, p)$ basis set and compared with the experimental data. The complete vibrational assignments of wave numbers were made on the basis of potential energy distribution using GAR2PED programme. Isotropic chemical shifts for ${ }^{1} \mathrm{H}$ and ${ }^{13} \mathrm{C}$ NMR were calculated using gauge-invariant atomic orbital (GIAO) method. The experimental vibrational frequencies, ${ }^{1} \mathrm{H}$ and ${ }^{13} \mathrm{C}$ NMR chemical shift values were found to be in good agreement with the theoretical values. On the basis of vibrational analysis, molecular electrostatic potential and the standard thermodynamic functions have been investigated.
\end{abstract}

(c) 2014 Elsevier B.V. All rights reserved.

\footnotetext{
* Corresponding author. Tel.: +91 8022961337; fax: +91 8022961331.

E-mail address: m_af_pasha@ymail.com (M.A. Pasha).
}

\section{Introduction}

Quinolinones are naturally occurring compounds; they exhibit a broad spectrum of pharmacological activities which include anticancer [1], antihypertensive [2], antiviral [2], and antibiotic [3] 
activities. Toxicity of quinolinone is known to be low when compared to that of other commonly used antimicrobial agents; hence, quinolinones are considered to be relatively well-tolerated agents [4]. They are potent chemotherapeutic agents and are used for the development of inhibitors for the treatment of a broad range of bacterial infections [5]. Inhibitory activity of quinolinones against cathepsin $\mathrm{V}$, a papain-like cysteine protease has been reported [6]. 2(1H)-Quinolinones have been reported to exhibit the cardiac stimulant activity [7] and methionyl-tRNA synthetase inhibition [8]. Quinolinone derivatives have also been patented for treating schizophrenia and related psychic disorders such as acute mania, bipolar disorder, autistic disorder and depression [9].

Literature survey reveals that, there are reports on the synthesis of quinolinones, but no structural study of such compounds seems to be present. Detailed knowledge on the molecular structure and spectral behavior of these compounds and their derivatives will aid the understanding of chemical and biological properties. In the present study, we describe the structural, vibrational, NMR and reactivity analyses of the derivatives of quinolinones viz., 2'-nitrophenyloctahydroquinolindione (2'-NOHQ) and its isomer $3^{\prime}$-nitrophenyloctahydroquinolindione $\left(3^{\prime}-\mathrm{NOHQ}\right)$ through spectral measurements. Theoretical calculations were carried out by density functional theory (B3LYP) method using 6-311++G (d,p) basis set. The calculated results were compared with the observed spectral values and were analyzed in detail. The aim of this work is to explore the molecular dynamics and the structural parameters which govern the chemical behavior, and to compare predictions made from the theory with the experimental observations.

\section{Materials and methods}

\section{Synthesis}

Occurrence of quinolinone scaffolds in a range of biologically active compounds, natural products and in the designed medicinal agents, necessitate the development of simple and efficient methods for the synthesis of quinolinones and their derivatives. Conventional methods of synthesis include the base-catalyzed Friedlander [10] and acid-catalyzed Knorr reactions [11]. Other reported methods are the Baylis-Hillman reaction [12], by the reduction of the nitro group into amino group using Zinc-Acetic acid followed by condensation sequence, and transition metal catalyzed cyclocarbonylation of 2-vinylanilines [13].

Reported methods are not completely satisfactory with regard to the yield, reaction conditions, cost of the reagents, catalysts, and due to involvement of multistep strategies.

Recently, we reported a multi-component synthesis of novel octahydroquinolindiones using $\mathrm{ZnO}$ as a readily available, inexpensive and environment friendly catalyst [14]. 2'-NOHQ and 3'-NOHQ were prepared by this method by refluxing a mixture of 2-nitrobenzaldehyde ( $1 \mathrm{mmol}$ ) or 3-nitrobenzaldehyde (1 mmol), diethyl malonate ( $1 \mathrm{mmol}), \mathrm{ZnO}(0.025 \mathrm{~g}, 7.5 \mathrm{~mol} \%)$ in water $(10 \mathrm{~mL})$ for $30 \mathrm{~min}$; dimedone $(1 \mathrm{mmol})$ and ammonium acetate $(2 \mathrm{mmol})$ were then added to the reaction mixture (Scheme 1) and refluxed for the remaining period ( $90 \mathrm{~min}$ ). The crude product obtained was filtered and washed with water; the dry solid residue was treated with dichloromethane and filtered to get $\mathrm{ZnO}$ which could be reused. The filtrate was then evaporated to get the desired product, which was subjected to silica gel column chromatography [silica gel G, 100-200 mesh] to get the pure product in $90 \%$ yield. The structures of both the products were confirmed by their FT-IR, ${ }^{1} \mathrm{H}$ NMR, ${ }^{13} \mathrm{C}$ NMR spectral analyses.

\section{Experimental details}

FT-IR spectra were recorded in the range $4000-400 \mathrm{~cm}^{-1}$ on a Bruker Optics Alpha-P FT-IR spectrophotometer with attenuated total reflectance (ATR) module. The FT-Raman spectra were recorded in solid phase on Bruker Optics Multi-RAM FT-Raman spectrophotometer using Nd-YAG laser operating at $1064 \mathrm{~nm}$ as an excitation source at the resolution of $4 \mathrm{~cm}^{-1}$. ${ }^{1} \mathrm{H}$ NMR and ${ }^{13} \mathrm{C}$ NMR spectra were obtained using a Bruker instrument operating at $400 \mathrm{MHz}$ and $100 \mathrm{MHz}$ respectively. Chemical shifts are reported on $\delta$ (delta) scale using tetra methyl silane as an internal standard and $\mathrm{CDCl}_{3}$ as solvent. Elemental analysis was carried out using vario MICRO V1.9.7 elemental analyzer. All the reactions were monitored by thin-layer chromatography (TLC). All the chemicals and solvents used were commercial and of analytical grade.

\section{Computational details}

Calculations for electronic structure and geometry optimization of the stable isomers of the molecule were done by DFT [15] using the Gaussian 09 program [16] package employing 6-311++G (d,p) basis sets and Becke's three parameter (local, nonlocal, HartreeFock) hybrid exchange functionals with Lee-Yang-Parr correlation functionals (B3LYP) [17-19]. The absolute Raman intensities and infrared absorption intensities were calculated in the harmonic approximation at the same level of theory as used for the optimized geometries from the derivatives of the dipole moment and polarizability of each normal mode respectively. We have used hybrid DFT B3LYP 6-311++G (d,p) method for vibrational frequency calculations, which is known to be very appropriate; although GGA is found to be accurate method for predicting many material properties including vibrational properties, for example: Sarrio et al. [20] presented a comparative study between different DFT method for vibrational property calculations of triatomic molecules and concluded that GGA is more appropriate method than hybrid functional method, and recently very accurate GGA based calculations by Adjokatse et al. [21] also proved the accuracy of this method in case of polymeric systems.

The normal-mode analysis was employed to calculate PED for each of the internal coordinates using localized symmetry $[22,23]$. For this purpose a complete set of 144 internal coordinates was defined using Pulay's recommendations [22,23]. The vibrational assignments of the normal modes were proposed on the basis of the PED calculations using the program GAR2PED [24]. Raman and IR spectra were simulated using a pure Lorentzian band profile $\left(\mathrm{fwhm}=10 \mathrm{~cm}^{-1}\right)$. Visualization and confirmation of the

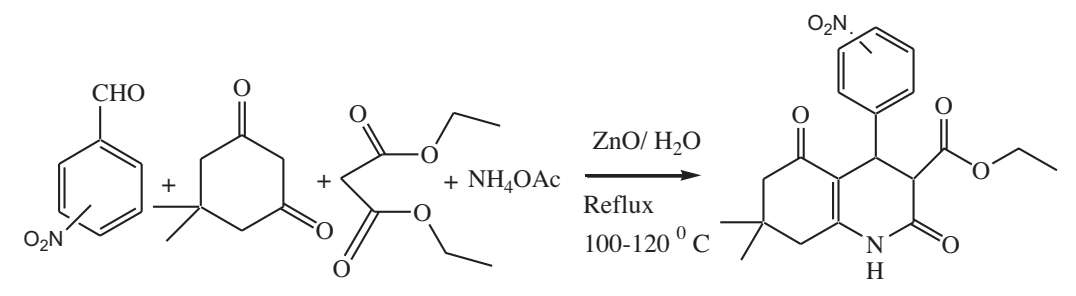

Scheme 1. 


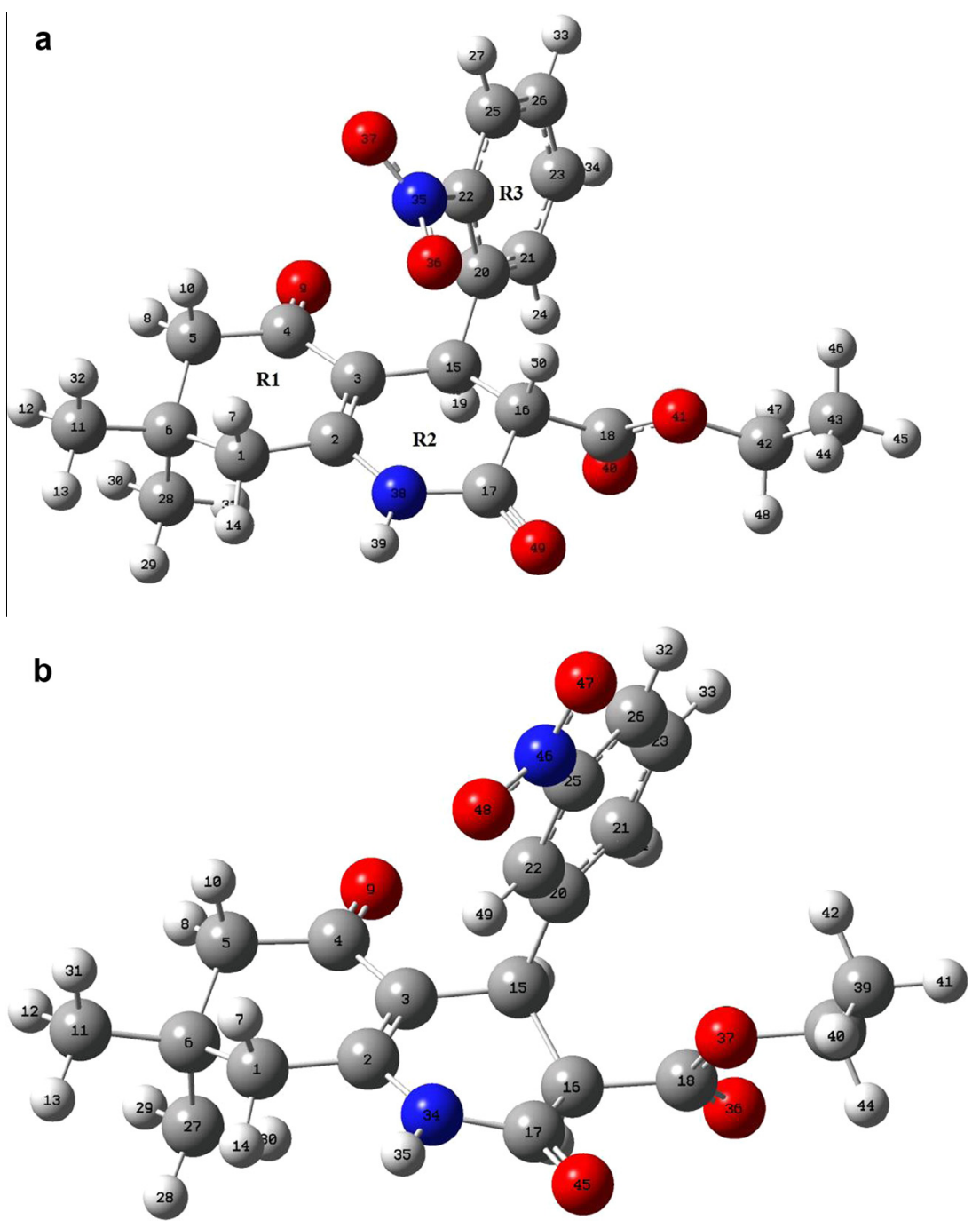

Fig. 1. Optimized structures of octahydroquinolindione isomers (a) $2^{\prime}-\mathrm{NOHQ}$ (b) $3^{\prime}-\mathrm{NOHQ}$.

calculated forms of the vibrations were done using the CHEMCRAFT program [25].

Calculated DFT vibrational wave numbers are known to be higher than the experimental wave numbers as the anharmonicity effects are neglected. The vibrational wave numbers were obtained from the DFT calculations using a dual scaling procedure for the fingerprint region (below $1800 \mathrm{~cm}^{-1}$ ) and $\mathrm{X}-\mathrm{H}$ stretching (above $1800 \mathrm{~cm}^{-1}$ ) regions respectively [26,27]. Recently, a few good papers using uniform scaling showed very good agreement between calculated and experimental frequencies [28]. In addition to uniform frequency scaling factors, dual scaling factors were determined to improve the agreement between computed and observed frequencies. The dual scaled error distributions are more symmetric, compared with the uniform scaled frequency errors [28]. All the calculated vibrational wavenumbers reported in this study are the scaled values.

\section{Results and discussion}

\section{Molecular geometry}

The molecular structures of both the isomers belong to $\mathrm{C} 1$ point group symmetry. The optimized molecular structures of the isomers were obtained from GAUSSIAN 09 program as shown in Fig. 1. The minimum energy of the title compound and its isomer was calculated to be -1336.539 by DFT method and -1336.546 by Hartree respectively. The enthalpy difference between these two molecules is $4.393 \mathrm{kcal} / \mathrm{mol}$. Since these energy differences are much larger than $k T$ (at room temperature), there is almost no possibility of coexistence of different molecules at room temperature.

The optimized structures of the $2^{\prime}$-NOHQ and $3^{\prime}$-NOHQ molecules were compared by superimposing them using a least-square algorithm which minimizes the distances between the corresponding non-hydrogen atoms (Fig. 2). The agreement between these molecules shows that, the geometry optimization almost reproduces the different conformations (overall average deviation $0.078 \AA$ ). The main differences are due to the position of the nitro group in the phenyl ring.

\section{Molecular electrostatic potential}

The molecular electrostatic potential (EPS) at a point $r$ in the space around a molecule is (in atomic units):

$V(r)=\sum_{A} \frac{Z A}{|\vec{R} A-\vec{r}|}-\int \frac{\rho\left(\vec{r}^{\prime}\right) d r^{\prime}}{\left|\vec{r}^{\prime}-\vec{r}\right|}$

$Z A$ is the charge on nucleus $A$, located at $R A$ and $\rho\left(r^{\prime}\right)$ is the electronic density function for the molecule. The first term in the 


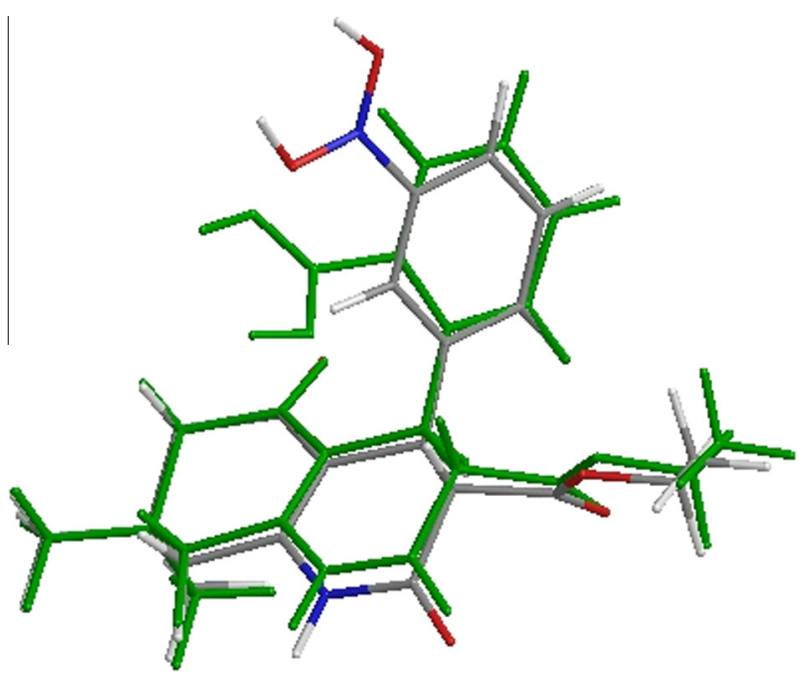

Fig. 2. Comparison of the $2^{\prime}$-nitrophenyl and $3^{\prime}$-nitrophenyl isomers of octahydroquinolindiones.

expression represents the effect of the nuclei; the second represents that of electrons. The two terms have opposite signs and therefore opposite effects. $V(r)$ is their resultant at each point $r$; it is an indication of the net electrostatic effect produced at the point $r$ by the total charge distribution (electrons + nuclei) of the molecule. EPS serves as a useful quantity to explain hydrogen bonding, reactivity and structure-activity relationship of molecules [29].

Electrostatic potential correlates with dipole moment, electronegativity, partial charges and site of chemical reactivity of the molecule. It provides a visual method to understand the relative polarity of a molecule. While the negative electrostatic potential corresponds to an attraction of the proton by the concentrated electron density in the molecule, the positive electrostatic potential corresponds to repulsion of the proton by atomic nuclei in regions where low electron density exists and the nuclear charge is incompletely shielded. By definition, the electron density isosurface is a surface on which molecule's electron density has a particular value and that encloses a specified fraction of the molecule's electron probability density. Coloring the isosurface with contours shows the electrostatic potential at different points on the electron density isosurface. The electron density isosurface on to which the electrostatic potential surface has been mapped are shown in Figs. 3 and 4 for 2'-NOHQ and 3'-NOHQ respectively. The different values of the electrostatic potential at the surface are represented by different colors; red represents regions of most negative electrostatic potential, blue represents regions of most positive electrostatic potential and green represents regions of zero potential. Potential increases in the order red $<$ orange $<$ yellow $<$ gre en $<$ blue.

\section{Vibrational analysis}

The total number of atoms in the $2^{\prime}$-NOHQ molecule is 50 resulting in $144(3 N-6)$ normal modes. Here, $N$ is the number of atoms in the molecule. The vibrational frequency and potential energy distribution of each normal modes obtained by DFT/ B3LYP methods using 6-311++G (d,p) basis set for 2'-NOHQ and its isomer are summarized in Table 1 . The title compound has the molecular formula of $\mathrm{C}_{20} \mathrm{H}_{22} \mathrm{O}_{6} \mathrm{~N}_{2}$, belongs to $\mathrm{C} 1$ point group and has 144 normal modes of fundamental vibrations.

DFT calculations yield Raman scattering amplitudes which cannot be taken directly to be the Raman intensities. The Raman scattering cross section, $\partial \sigma_{\mathrm{j}} / \partial \Omega$, which are proportional to Raman intensity may be calculated from the Raman scattering amplitude and predicted wavenumbers for each normal mode using the relationship [30,31].

$$
\frac{\partial \sigma_{j}}{\partial \Omega}=\left(\frac{2^{4} \pi^{4}}{45}\right)\left(\frac{\left(v_{0}-v_{j}\right)^{4}}{1-\exp \left[\frac{-h c v_{j}}{k T}\right]}\right)\left(\frac{h}{8 \pi^{2} c v_{j}}\right) S_{j}
$$

where $S_{j}$ and $v_{j}$ are the scattering activities and the predicted wavenumbers, respectively of the $j$ th normal mode, $v_{0}$ is the wavenum-

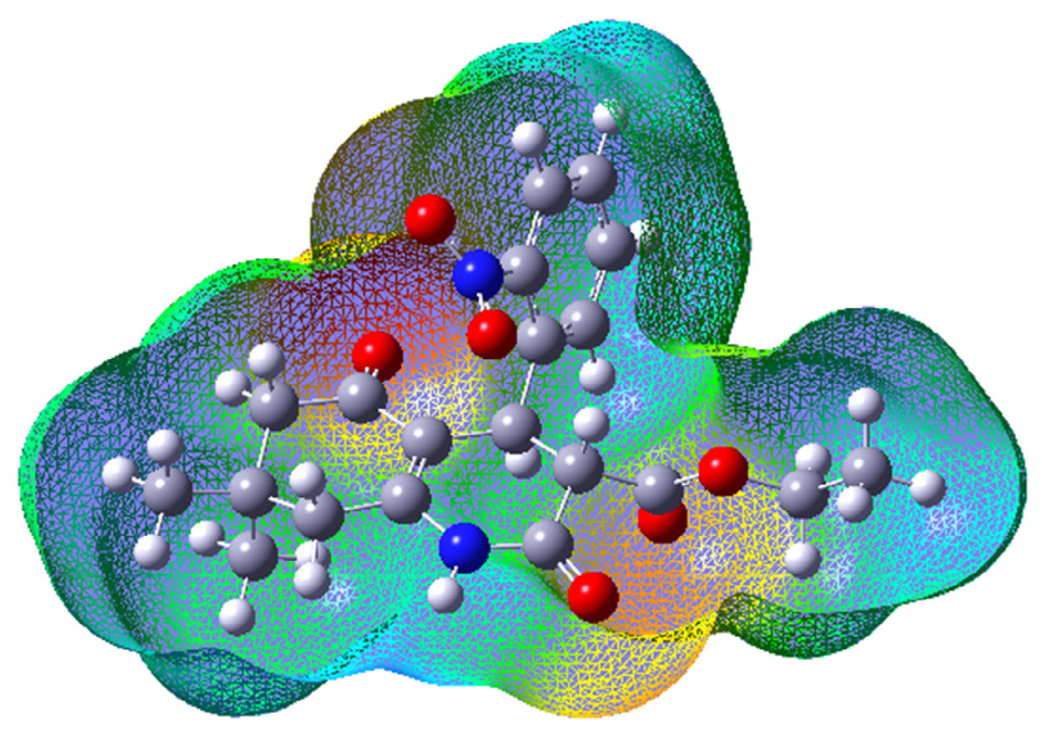

\begin{tabular}{|l|l|l}
\hline 5770062 & $5.700=2$ \\
\hline
\end{tabular}

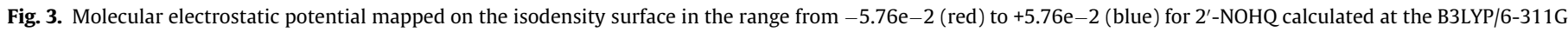
$(d, p)$ level of theory. (For interpretation of the references to color in this figure legend, the reader is referred to the web version of this article.) 


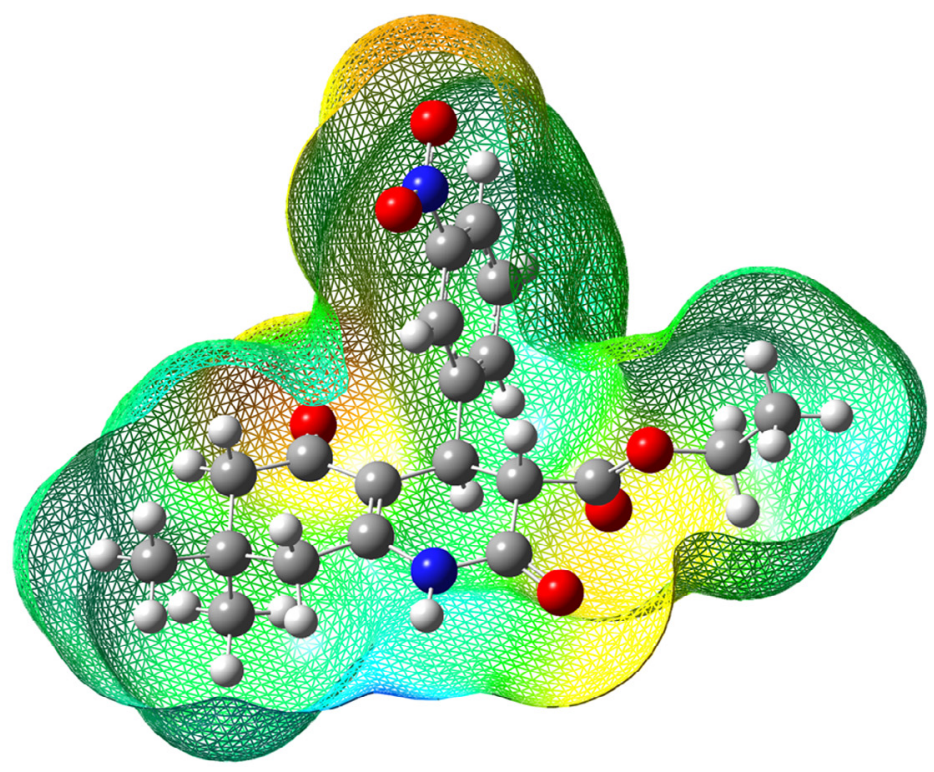

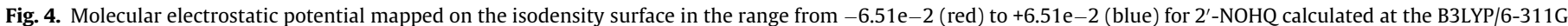
$(\mathrm{d}, \mathrm{p})$ level of theory. (For interpretation of the references to color in this figure legend, the reader is referred to the web version of this article.)

ber of the Raman excitation line and $h, c$ and $k$ are universal constants. The Raman intensities obtained using this relationship match quite nicely with the experimentally observed intensities as shown in Figs. 5 and 6.

\section{Vibrational wavenumbers}

Comparison of calculated wavenumbers at the B3LYP/6-311++G $(\mathrm{d}, \mathrm{p})$ level with experimental values reveals an overestimation of the wavenumber of the vibrational modes due to neglect of anharmonicity present in real system. Since the vibrational wavenumbers obtained from the DFT calculations are higher than the experimental wavenumbers. Figs. 5-8 show a comparison between experimental and calculated Raman and IR spectra for $2^{\prime}$-NOHQ and $3^{\prime}-\mathrm{NOHQ}$.

\section{Ring vibrations}

The $\mathrm{C}-\mathrm{H}$ stretching vibration in ring is usually strong in both the IR and Raman spectra. $\mathrm{C}-\mathrm{H}$ stretching vibrations of aromatic structures generally occur in the region $3100-2800 \mathrm{~cm}^{-1}$ [32] which is the characteristic of $\mathrm{C}-\mathrm{H}$ stretching vibration. The IR bands observed at 3099, 3090, 3075, and $3065 \mathrm{~cm}^{-1}$, and Raman bands at 3080 and $3069 \mathrm{~cm}^{-1}$ are assigned to stretching vibrations of the phenyl ring modes in Ring 3 . These bands show a very good agreement with the scaled vibrations obtained. The aromatic inplane $\mathrm{C}-\mathrm{H}$ bending and out-of-plane bending vibrations normally occur in the region $1300-1000 \mathrm{~cm}^{-1}$ and $750-1000 \mathrm{~cm}^{-1}$, respectively [33]. The $v(\mathrm{CH})$ wavenumber in Ring 2 is assigned at 2908 and $2769 \mathrm{~cm}^{-1}$ in the IR spectra and calculated to be at 2988 and $2935 \mathrm{~cm}^{-1}$.

The $v\left(\mathrm{CH}_{2}\right)$ wavenumber in Ring 1 is assigned at 2857, 2743, 2722 , and $2714 \mathrm{~cm}^{-1}$ in the IR spectra and at 2775 and $2725 \mathrm{~cm}^{-1}$ in the Raman spectra.

The $\mathrm{N} \mathrm{H}$ stretching vibrations are weaker and sharper, and occur in the region $3500-3300 \mathrm{~cm}^{-1}$ [34]. This band is intense in infrared spectra but not observed in Raman spectrum. For 2'-NOHQ, the N H stretch is calculated to be at $3591 \mathrm{~cm}^{-1}$ corresponds to $3393 \mathrm{~cm}^{-1}$ in IR spectrum. This is a pure mode having $99 \%$ contribution from the $\mathrm{NH}$ stretching internal coordinate and it is quite overestimated in the calculations. In amides the out-of-plane $\mathrm{NH}$ deformation is expected in the region $650 \pm 50 \mathrm{~cm}^{-1}$ [35] and bands at $685 \mathrm{~cm}^{-1}$ in the IR spectra, $660 \mathrm{~cm}^{-1}$ in the Raman spectra are assigned as this mode is calculated at $663 \mathrm{~cm}^{-1}$.

The compounds containing nitro group are readily identified by asymmetric bands which observed in the region $1550-1490 \mathrm{~cm}^{-1}$. In the $2^{\prime}-\mathrm{NOHQ}$, band found at $1519 \mathrm{~cm}^{-1}$ (IR) and $1524 \mathrm{~cm}^{-1}$ (Raman) calculated at $1561 \mathrm{~cm}^{-1}$ is attributed to $\mathrm{NO}_{2}$ asymmetric stretching vibrations, and thus coincides well with the experimental observations.

In $2^{\prime}-\mathrm{NOHQ}$ the bands at $1290,1262,1215$, and $1182 \mathrm{~cm}^{-1}$ (IR) are assigned to $\mathrm{C}-\mathrm{H}$ in-plane bending vibrations. Corresponding bands are observed at 1287, 1249, 1211 and $1195 \mathrm{~cm}^{-1}$ in $3^{\prime}$ NOHQ. The IR bands at 987, 957, 890, 787 and $743 \mathrm{~cm}^{-1}$ are assigned to $\mathrm{C}-\mathrm{H}$ out-of-plane bending vibrations.

\section{Methyl and methylene group vibrations}

Three methyl groups are present in the molecule. Two of them are directly connected to the Ring 1 , and the other one is connected to the $\mathrm{CH}_{2}$ group in the side chain of Ring 2. The asymmetric stretching mode of methyl group is expected to be around $2980 \mathrm{~cm}^{-1}$ and symmetric stretching at $2870 \mathrm{~cm}^{-1}$ [36,37]. In $2^{\prime}-$ NOHQ the modes appearing at 2997, 2825 and $2790 \mathrm{~cm}^{-1}$ are assigned to $\mathrm{CH}_{3}$ anti-symmetric stretching modes. The $\mathrm{CH}_{3}$ symmetric stretching normal modes are assigned to bands at 2753 , 2736 and $2729 \mathrm{~cm}^{-1}$ in the IR spectrum and at 2939, 2926 and $2779 \mathrm{~cm}^{-1}$ in the Raman spectrum.

The symmetric and asymmetric bending vibrations of methyl group are normally expected in the regions $1465-1440 \mathrm{~cm}^{-1}$. The asymmetric bending of methyl groups observed at 1427, 1410 and $1386 \mathrm{~cm}^{-1}$ in the IR and 1425,1414 and $1385 \mathrm{~cm}^{-1}$ in the Raman spectra are in good agreement with the calculated values. The corresponding experimental wavenumbers for $3^{\prime}-\mathrm{NOHQ}$ are observed at 1417 and $1374 \mathrm{~cm}^{-1}$ in the IR spectrum.

The asymmetric and symmetric stretching bands of methylene hydrogens $\left(\mathrm{C}_{2} \mathrm{H}_{2}\right)$ in $2^{\prime}$-NOHQ were observed at 2876 and $2781 \mathrm{~cm}^{-1}$ 
Table 1 PED

\begin{tabular}{|c|c|c|c|c|c|}
\hline \multicolumn{3}{|c|}{ Calculated } & \multicolumn{2}{|c|}{ Observed } & \multirow[t]{2}{*}{$\mathrm{PED}^{\mathrm{b}}$} \\
\hline Unscaled & $\begin{array}{l}\text { Scaled } \\
2^{\prime} \text {-NOHQ } \\
\end{array}$ & $\begin{array}{l}\text { Scaled } \\
3^{\prime} \text {-NOHQ }\end{array}$ & IR & Raman & \\
\hline 3591 & 3468 & 3468 & 3393 & - & $v(\mathrm{~N} 38-\mathrm{H})(99)$ \\
\hline 3215 & 3106 & 3115 & 3099 & - & $\mathrm{R} 3[\mathrm{v}(\mathrm{C}-\mathrm{H})](98)$ \\
\hline 3197 & 3088 & 3096 & 3090 & - & $\mathrm{R} 3[\mathrm{v}(\mathrm{C}-\mathrm{H})](100)$ \\
\hline 3190 & 3081 & 3085 & 3075 & 3080 & $\mathrm{R} 3[\mathrm{v}(\mathrm{C}-\mathrm{H}](94)$ \\
\hline 3175 & 3067 & 3071 & 3065 & 3069 & $\mathrm{R} 3[\mathrm{v}(\mathrm{C}-\mathrm{H})](98)$ \\
\hline 3119 & 3013 & 3014 & 3018 & 3038 & $\operatorname{Me} 3\left[\mathrm{v}\left(\mathrm{CH}_{3}\right)\right](68)+\mathrm{CH}_{2}[\mathrm{v}(\mathrm{C} 42 \mathrm{H})](31)$ \\
\hline 3105 & 2999 & 2999 & 3001 & - & Me3 $[\mathrm{v}(\mathrm{C} 43-\mathrm{H} 45)](94)+\mathrm{CH}_{2}[\mathrm{v}(\mathrm{C} 42 \mathrm{H})](5)$ \\
\hline 3096 & 2991 & 2990 & 2997 & - & Me2[u(C28-H31)](91) \\
\hline 3093 & 2988 & 2989 & 2908 & - & $\mathrm{R} 2[\mathrm{v}(\mathrm{C} 16-\mathrm{H} 50)](98)$ \\
\hline 3093 & 2987 & 2986 & 2876 & - & $\mathrm{CH}_{2}[\mathrm{v}(\mathrm{C} 42 \mathrm{H})](64)+\mathrm{Me} 3[\mathrm{v}(\mathrm{C} 43-\mathrm{H})](33)$ \\
\hline 3091 & 2986 & 2983 & 2869 & - & $\mathrm{R} 1 \mathrm{v}\left(\mathrm{CH}_{2}\right)(34)+\mathrm{Me} 1[\mathrm{v}(\mathrm{C} 11-\mathrm{H})](39)+\mathrm{Me} 2[\mathrm{v}(\mathrm{C} 28-\mathrm{H})](21)$ \\
\hline 3087 & 2982 & 2982 & 2857 & - & $\mathrm{R} 1\left[\mathrm{v}\left(\mathrm{CH}_{2}\right)\right](48)+\operatorname{Me} 1[\mathrm{v}(\mathrm{C} 11-\mathrm{H})](46)$ \\
\hline 3086 & 2981 & 2975 & 2825 & - & $\operatorname{Me} 2[\mathrm{v}(\mathrm{C} 28-\mathrm{H})](68)+\mathrm{Me} 1[\mathrm{v}(\mathrm{C} 11-\mathrm{H})](21)+\mathrm{R} 1[\mathrm{v}(\mathrm{C} 5-\mathrm{H} 8)](5)$ \\
\hline 3079 & 2974 & 2954 & 2790 & 2962 & $\operatorname{Me} 1[\mathrm{v}(\mathrm{C} 11-\mathrm{H})](87)+\mathrm{Me} 2[\mathrm{v}(\mathrm{C} 28-\mathrm{H})](12)$ \\
\hline 3056 & 2952 & 2943 & 2781 & 2949 & $\mathrm{CH}_{2}[\mathrm{v}(\mathrm{C} 42 \mathrm{H})](97)$ \\
\hline 3039 & 2935 & 2935 & 2769 & - & $v(\mathrm{C} 15-\mathrm{H} 19)(98)$ \\
\hline 3038 & 2934 & 2932 & 2753 & 2939 & Me3[v(C43-H)](99) \\
\hline 3036 & 2933 & 2931 & 2743 & - & $\mathrm{R} 1\left[\mathrm{v}\left(\mathrm{CH}_{2}\right](96)\right.$ \\
\hline 3026 & 2923 & 2923 & 2736 & 2926 & $\operatorname{Me} 2[v(\mathrm{C} 28-\mathrm{H})](81)+\operatorname{Me} 1[\mathrm{v}(\mathrm{C} 11-\mathrm{H} 13)](5)$ \\
\hline 3017 & 2914 & 2916 & 2729 & 2779 & $\operatorname{Me} 1[v(\mathrm{C} 11-\mathrm{H})](79)+\mathrm{Me} 2[\mathrm{v}(\mathrm{C} 28-\mathrm{H})](13)$ \\
\hline 3010 & 2908 & 2905 & 2722 & 2775 & $\mathrm{R} 1\left[\mathrm{v}\left(\mathrm{CH}_{2}\right)\right](93)$ \\
\hline 3002 & 2899 & 2899 & 2714 & 2725 & $\mathrm{R} 1\left[\mathrm{v}\left(\mathrm{CH}_{2}\right)\right](98)$ \\
\hline 1787 & 1774 & 1780 & 1719 & 1720 & $\mathrm{COO}[\mathrm{v}(\mathrm{C} 18-040)](66)+\mathrm{R} 2[\mathrm{v}(\mathrm{C} 17-049)](14)+\mathrm{R} 2 \delta(\mathrm{C} 16)(5)$ \\
\hline 1767 & 1754 & 1760 & 1618 & 1614 & $\mathrm{R} 2[\mathrm{v}(\mathrm{C} 17=049)](62)+\mathrm{COO}[\mathrm{v}(\mathrm{C} 18-040)](15)$ \\
\hline 1711 & 1699 & 1708 & 1520 & 1578 & $R 1[v(C=0](78)+v(C 2=C 3)(6)$ \\
\hline 1674 & 1662 & 1655 & - & - & $\mathrm{v}(\mathrm{C} 2=\mathrm{C} 3)(58)+\mathrm{R} 1\left[\mathrm{v}(\mathrm{C}=0](7)+\mathrm{R} 1\left[\delta_{a s}\right.\right.$ ring $](6)$ \\
\hline 1645 & 1633 & 1645 & - & - & $\mathrm{R} 3[\mathrm{v}(\mathrm{C}-\mathrm{C})](59)+\mathrm{R} 3\left[\delta_{a s}\right.$ ring $](9)+\delta(\mathrm{CC} 21 \mathrm{H})(6)+\delta(\mathrm{CN} 35 \mathrm{C})(5)+\delta(\mathrm{CC} 23 \mathrm{H})(5)$ \\
\hline 1613 & 1601 & 1609 & - & - & $\mathrm{R} 3[\mathrm{v}(\mathrm{C}-\mathrm{C})](63)+\delta(\mathrm{C} 22 \mathrm{H} 33)(10)+\mathrm{R} 3\left[\delta_{\text {ring }}\right](9)$ \\
\hline 1573 & 1561 & 1569 & - & - & $v(N 350)(79)+\rho(N 35 C 22)(6)$ \\
\hline 1516 & 1505 & 1506 & 1519 & 1524 & $\left.\delta\left(\mathrm{C}_{2} \mathrm{H}_{2}\right)(68)+\mathrm{Me} 3[\delta(\mathrm{C} 43 \mathrm{H} 46)] 16\right)+\mathrm{Me} 3\left[\delta_{\mathrm{as}}(\mathrm{HCH})\right](6)$ \\
\hline 1513 & 1502 & 1501 & - & - & $\mathrm{R} 3[\mathrm{v}(\mathrm{C}-\mathrm{C})](28)+\mathrm{R} 3[\delta(\mathrm{CC} 21 \mathrm{H})](33)+\delta(\mathrm{CN} 35 \mathrm{C})(18)$ \\
\hline 1512 & 1501 & 1500 & - & - & $\operatorname{Me} 2[\rho(\mathrm{CH})](51)+\operatorname{Me} 1[\rho(\mathrm{C} 6 \mathrm{C} 11)] 34)+\operatorname{Me} 2[\delta(\mathrm{C} 6 \mathrm{C} 28)](5)$ \\
\hline 1507 & 1496 & 1495 & - & - & $\operatorname{Me} 2\left[\delta_{\mathrm{as}}(\mathrm{CH})\right](45)+\operatorname{Me} 1\left[\delta_{\mathrm{s}}(\mathrm{CH})\right](41)$ \\
\hline 1498 & 1487 & 1488 & - & - & $\operatorname{Me} 1\left[\delta_{\mathrm{s}}(\mathrm{CH})\right](43)+\delta\left(\mathrm{C}_{2} \mathrm{H}_{2}\right)(31)+\operatorname{Me} 3\left[\delta_{\mathrm{as}}(\mathrm{CH})\right](18)$ \\
\hline 1496 & 1485 & 1484 & - & - & $\operatorname{Me} 1\left[\delta_{\mathrm{s}}(\mathrm{CH})\right](37)+\operatorname{Me} 2\left[\delta_{\mathrm{as}}(\mathrm{CH})\right](27)+\mathrm{R} 1\left[\delta\left(\mathrm{CH}_{2}\right)\right](18)$ \\
\hline 1493 & 1482 & 1478 & - & - & $\mathrm{R} 2[\delta(\mathrm{CN} 38)](44)+\mathrm{R} 2[\mathrm{v}(\mathrm{C} 2-\mathrm{N} 38)](23)$ \\
\hline 1487 & 1477 & 1476 & - & - & $\operatorname{Me} 1[\rho(\mathrm{C} 6 \mathrm{C} 11)](50)+\operatorname{Me} 2[\rho(\mathrm{CH})](35)$ \\
\hline 1486 & 1475 & 1476 & - & - & $\operatorname{Me} 3\left[\delta_{\mathrm{as}}(\mathrm{C} 43 \mathrm{H})\right](91)+\delta(\mathrm{C} 42 \mathrm{C} 43)(7)$ \\
\hline 1474 & 1463 & 1462 & 1468 & 1466 & $\delta(\mathrm{C} 22 \mathrm{H} 33)(22)+\delta(\mathrm{CC} 23 \mathrm{H})(20)+\mathrm{R} 3[\mathrm{v}(\mathrm{C}-\mathrm{C})](29)+\mathrm{R} 2[\delta(\mathrm{C} 15 \mathrm{H})](6)+\delta(\mathrm{CN} 35 \mathrm{C})(5)$ \\
\hline 1473 & 1462 & 1462 & - & - & $\mathrm{R} 1\left[\delta\left(\mathrm{CH}_{2}\right)\right](72)+\operatorname{Me} 2\left[\delta_{a s}(\mathrm{CH})\right](12)+\operatorname{Me} 1\left[\delta_{s}(\mathrm{CH})\right](7)$ \\
\hline 1464 & 1453 & 1453 & 1449 & 1477 & $\mathrm{R} 1\left[\delta\left(\mathrm{CH}_{2}\right)\right](94)$ \\
\hline 1427 & 1417 & 1418 & 1427 & 1425 & $\operatorname{Me} 2\left[\delta_{\mathrm{s}}(\mathrm{C} 28)\right](50)+\operatorname{Me} 1\left[\delta_{\mathrm{s}}(\mathrm{C} 11)\right](37)$ \\
\hline 1426 & 1416 & 1415 & 1410 & 1414 & $\operatorname{Me} 3\left[\delta_{\mathrm{s}}(\mathrm{CH})\right](50)+\omega\left(\mathrm{C}_{2} \mathrm{H}_{2}\right)(26)+\mathrm{v}(\mathrm{C} 42 \mathrm{C})(13)$ \\
\hline 1405 & 1395 & 1394 & - & - & $\operatorname{Me} 1[\delta(\mathrm{C} 11)](54)+\delta(\mathrm{C} 28 \mathrm{HC})(38)$ \\
\hline 1399 & 1389 & 1391 & 1386 & 1385 & $\omega\left(\mathrm{C}_{2} \mathrm{H}_{2}\right)(43)+\mathrm{Me} 3\left[\delta_{\mathrm{s}}\left(\mathrm{CH}_{3}\right)\right](37)$ \\
\hline 1391 & 1381 & 1376 & - & - & $\mathrm{R} 2[\delta(\mathrm{C} 15 \mathrm{H})](36)+\mathrm{R} 2[\rho(\mathrm{C} 15 \mathrm{H})](12)+\delta(\mathrm{CN} 35 \mathrm{C})(6)$ \\
\hline 1387 & 1377 & 1363 & - & - & $\mathrm{R} 1[\omega(\mathrm{CCH})](42)+\mathrm{R} 1[\mathrm{v}(\mathrm{C}-\mathrm{C})](15)+\mathrm{R} 1\left[\delta_{a s}\right.$ ring $](6)$ \\
\hline 1378 & 1368 & 1358 & 1355 & 1358 & $\mathrm{v}(\mathrm{N} 35 \mathrm{O})(55)+\delta\left(\mathrm{NO}_{2}\right)(15)+\mathrm{R} 3[\mathrm{v}(\mathrm{C} 22-\mathrm{N} 35)](15)$ \\
\hline 1363 & 1353 & 1352 & 1354 & 1344 & $\mathrm{R} 2[\omega(\mathrm{C} 15 \mathrm{H})](22)+\mathrm{R} 2[\gamma(\mathrm{C} 15 \mathrm{H})](13)+\mathrm{R} 2[\delta(\mathrm{C} 16 \mathrm{H})](9)+\mathrm{R} 2[\omega(\mathrm{C} 16 \mathrm{H})](9)+\mathrm{R} 2[\gamma(\mathrm{C} 16 \mathrm{H})](7)+\mathrm{v}(\mathrm{C} 16-\mathrm{C} 18)](5)+\omega\left(\mathrm{C} 42 \mathrm{H}_{2}\right)(5)+\mathrm{R} 2[\rho(\mathrm{C} 16)](5)+\mathrm{R} 2[\mathrm{v}(\mathrm{C} 15-\mathrm{C} 16](5)$ \\
\hline 1346 & 1336 & 1335 & - & - & $\mathrm{R} 1[\mathrm{v}(\mathrm{C}-\mathrm{C})](30)+\mathrm{R} 1[\delta(\mathrm{C}=0)](7)+\mathrm{R} 2[\mathrm{v}(\mathrm{C} 3-\mathrm{C} 15)](7)+\mathrm{R} 2[\mathrm{v}(\mathrm{C} 17-\mathrm{N} 38)](5)+\mathrm{R} 2[\delta(\mathrm{C} 16 \mathrm{H})](5)+\mathrm{R} 2\left[\delta_{\text {ring }}\right](5)$ \\
\hline 1338 & 1328 & 1330 & - & - & $\mathrm{R} 3[\mathrm{v}(\mathrm{C}-\mathrm{C})](66)+\delta(\mathrm{CC} 21 \mathrm{H})(14)+\delta(\mathrm{C} 22 \mathrm{H} 33)(6)$ \\
\hline 1325 & 1316 & 1313 & - & - & $\mathrm{R} 2[\omega(\mathrm{C} 16 \mathrm{H})](20)+\mathrm{R} 2[\gamma(\mathrm{C} 16 \mathrm{H})](14)+\mathrm{R} 2[\delta(\mathrm{C} 16 \mathrm{H})](10)+\mathrm{R} 1[\gamma(\mathrm{CC} 1 \mathrm{H})](6)$ \\
\hline
\end{tabular}




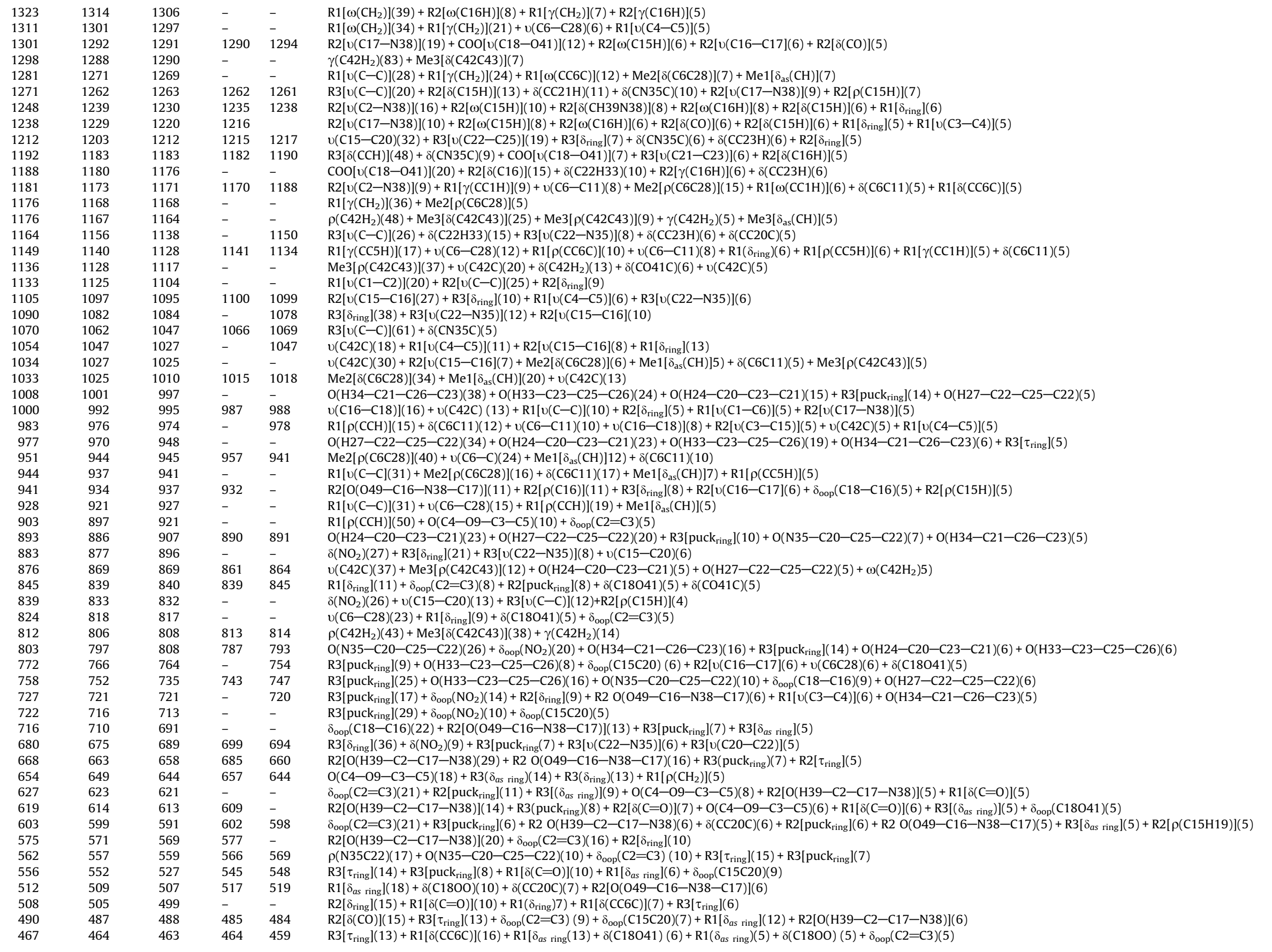


a Proposed assignment and potential energy distribution (PED) for vibrational normal modes. Types of vibration: $v$, stretching; $\delta$, deformation; 0 , out-of-plane bending; $\omega$, wagging; $\gamma$, twisting; $\rho$, rocking; $\tau$, torsion.

b Potential energy distribution (contributing $\geqslant 5$ ) for 2'-NOHQ. 


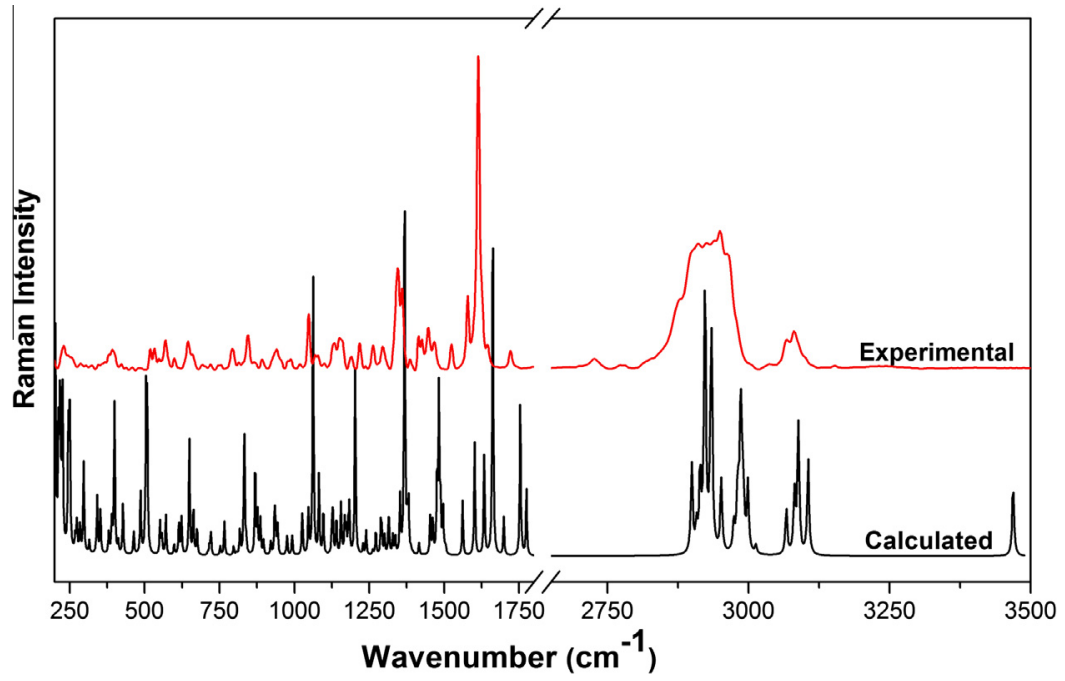

Fig. 5. FT-Raman spectrum of $2^{\prime}-\mathrm{NOHQ}$.

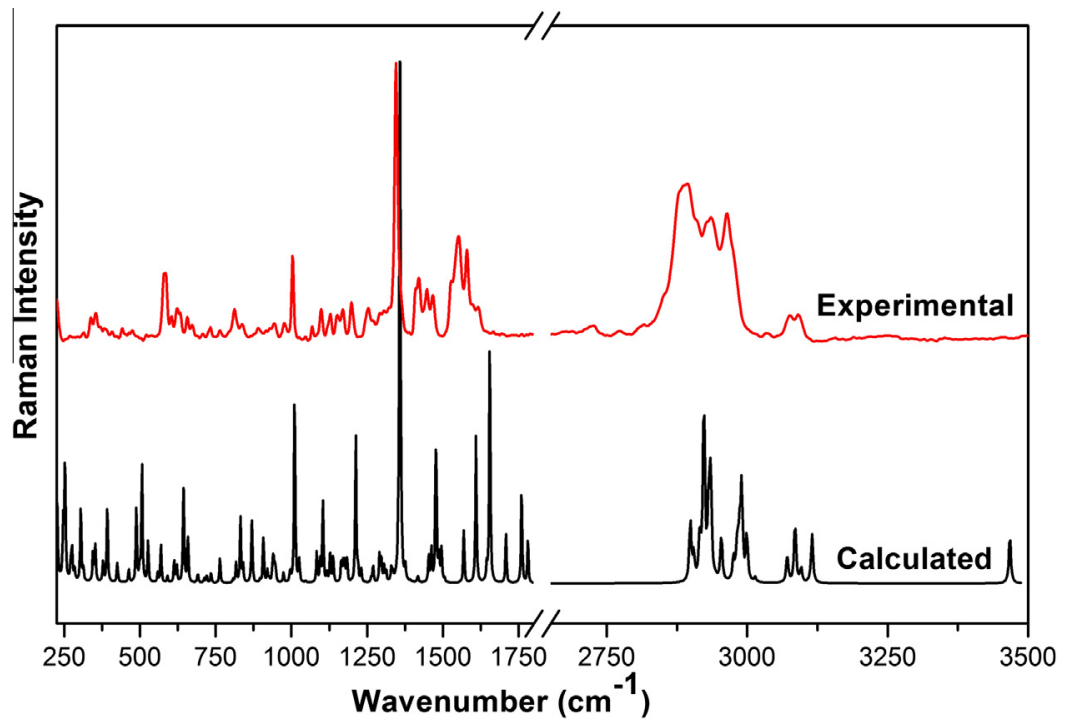

Fig. 6. FT-Raman spectrum of $3^{\prime}-\mathrm{NOHQ}$.

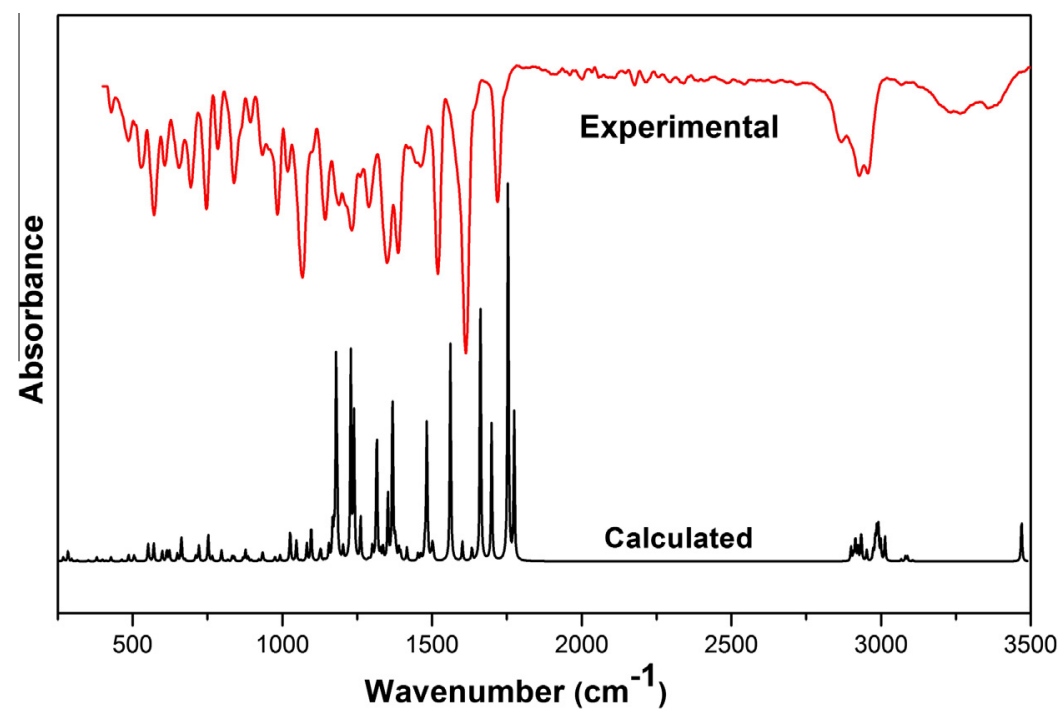

Fig. 7. FT-IR spectrum of $2^{\prime}-\mathrm{NOHQ}$. 


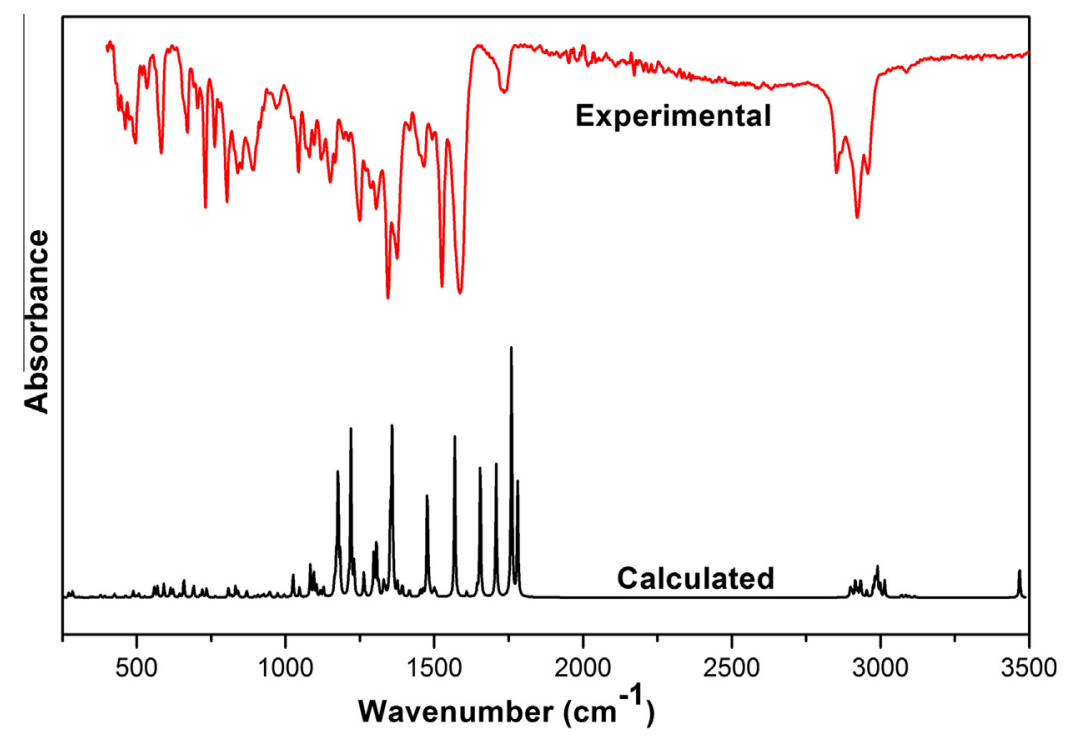

Fig. 8. FT-IR spectrum of $3^{\prime}-\mathrm{NOHQ}$.

\section{Carbonyl group vibrations}

Esters show a very strong band for the $\mathrm{C}=\mathrm{O}$ group in the range of $17,501,735 \mathrm{~cm}^{-1}$. Stretching mode of $\mathrm{C} 18040$ in $2^{\prime}$-NOHQ is observed at $1719 \mathrm{~cm}^{-1}$ in IR as a very strong band and at $1720 \mathrm{~cm}^{-1}$ in Raman as a weak band. A very strong band of the amide carbonyl stretching vibration is observed at $1618 \mathrm{~cm}^{-1}$ in the IR and $1614 \mathrm{~cm}^{-1}$ in the Raman spectra. The cyclic ketone appears at $1520 \mathrm{~cm}^{-1}$ in the IR spectra and $1578 \mathrm{~cm}^{-1}$ in the Raman spectra. In 3'-NOHQ, these modes appear at $1736,1587,1525 \mathrm{~cm}^{-1}$ in the IR and $1612,1578,1551 \mathrm{~cm}^{-1}$ in the Raman spectra. It is observed from Table 1 that the calculated vibrational frequencies of both the isomers are very close to the experimental values.

\section{NMR spectra}

${ }^{1} \mathrm{H}$ and ${ }^{13} \mathrm{C}$ NMR chemical shifts were calculated at the B3LYP/6$311++G(d, p)$ level. The experimental and theoretical values of ${ }^{1} \mathrm{H}$ and ${ }^{13} \mathrm{C}$ NMR spectra of $2^{\prime}$-NOHQ are given in Table 2. The ${ }^{13} \mathrm{C}$

Table 2

Observed and calculated NMR chemical shifts ( $\delta \mathrm{ppm})$ for $2^{\prime}$-NOHQ.

\begin{tabular}{|c|c|c|c|c|c|c|c|}
\hline Atom & $\begin{array}{l}\delta \\
\text { (Calculated) }\end{array}$ & $\begin{array}{l}\delta \\
\text { (Expt.) }\end{array}$ & $\Delta^{\mathrm{a}}$ & Atom & $\begin{array}{l}\delta \\
\text { (Calculated) }\end{array}$ & $\begin{array}{l}\delta \\
\text { (Expt.) }\end{array}$ & $\Delta^{\mathrm{a}}$ \\
\hline C1 & 46.36 & 46.8 & -0.44 & $\mathrm{H} 7$ & 2.49 & 2.35 & 0.14 \\
\hline $\mathrm{C} 2$ & 153.64 & 115.2 & 38.44 & $\mathrm{H} 8$ & 1.70 & 2.4 & -0.70 \\
\hline C3 & 118.92 & 148.8 & -29.88 & $\mathrm{H} 10$ & 1.89 & 2.4 & -0.51 \\
\hline C4 & 203.83 & 191.6 & 12.23 & H12 & 0.75 & 1.11 & -0.36 \\
\hline C5 & 55.89 & 32.3 & 23.59 & $\mathrm{H} 13$ & 0.77 & 1.11 & -0.34 \\
\hline C6 & 43.23 & 30.1 & 13.13 & H14 & 1.35 & 2.35 & -1.00 \\
\hline C11 & 31.59 & 26.1 & 5.49 & H19 & 4.93 & 4.45 & 0.48 \\
\hline C15 & 59.07 & 31.9 & 27.17 & $\mathrm{H} 24$ & 8.38 & 7.24 & 1.14 \\
\hline C16 & 56.06 & 47.4 & 8.66 & $\mathrm{H} 27$ & 9.50 & 7.47 & 2.03 \\
\hline C17 & 171.51 & 178.1 & -6.59 & $\mathrm{H} 29$ & 0.45 & 1.11 & -0.66 \\
\hline C18 & 186.62 & 161.8 & 24.82 & H30 & 0.55 & 1.11 & -0.56 \\
\hline $\mathrm{C} 20$ & 140.98 & 135.3 & 5.68 & H31 & 1.22 & 1.11 & 0.11 \\
\hline $\mathrm{C} 21$ & 146.61 & 122.7 & 23.91 & H32 & 0.69 & 1.11 & -0.42 \\
\hline $\mathrm{C} 22$ & 161.08 & 133.3 & 27.78 & H33 & 7.33 & 7.08 & 0.25 \\
\hline $\mathrm{C} 23$ & 140.39 & 129.5 & 10.89 & H34 & 7.53 & 7.44 & 0.09 \\
\hline $\mathrm{C} 25$ & 140.02 & 115.2 & 24.82 & H39 & 6.12 & 10.86 & -4.74 \\
\hline C26 & 131.96 & 121.5 & 10.46 & $\mathrm{H} 44$ & 2.61 & 1.23 & 1.38 \\
\hline C28 & 25.63 & 27.6 & -1.97 & $\mathrm{H} 45$ & 2.22 & 1.23 & 0.99 \\
\hline C42 & 37.46 & 54.8 & -17.34 & $\mathrm{H} 46$ & 1.87 & 1.23 & 0.64 \\
\hline \multirow[t]{3}{*}{ C43 } & 24.83 & 16.2 & 8.63 & $\mathrm{H} 47$ & 9.56 & 4.09 & 5.47 \\
\hline & & & & H48 & 8.30 & 4.09 & 4.21 \\
\hline & & & & H50 & 3.76 & 6.05 & -2.29 \\
\hline
\end{tabular}

${ }^{\mathrm{a}} \delta_{\text {calculated }}-\delta_{\text {expt }}$. and ${ }^{1} \mathrm{H}$ NMR spectra in DMSO-d6 are presented in Fig. 9. The singlet observed at $10.86 \mathrm{ppm}$ is assigned to $\mathrm{N} \mathrm{H}$ and this has been computed to be at $6.12 \mathrm{ppm}$. The phenyl protons resonate as the multiplet at $7.49-8.26 \mathrm{ppm}$ experimentally and these have been predicted in the range $7.33-9.50 \mathrm{ppm}$. A singlet at 2.35 and $2.40 \mathrm{ppm}$ correspond to the methylene hydrogens of the ring and the singlet at 4.09 to the methylene protons of the side chain. In the ${ }^{13} \mathrm{C}$ NMR spectrum, C18 in Ring 2 and C22 in Ring 3 appear at lower chemical shift of 161.8 and $133.3 \mathrm{ppm}$ due to neighboring electronegative oxygen and nitrogen atoms. C42 appears at higher field of $54.8 \mathrm{ppm}$ due the methyl and the ester groups attached to it. The carbonyl carbon C4 at 191.30 ppm, methyl carbons C11, C28, and C43 at 26.1, 27.6, and 16.2 are in good agreement with the predicted chemical shifts. It is observed from Table 2 that the predicted chemical shift values are in closer agreement with the experimental values. The experimental and theoretical values of ${ }^{1} \mathrm{H}$ and ${ }^{13} \mathrm{C}$ NMR for $3^{\prime}$-NOHQ are given in the Table $\mathrm{S} 2$ as a supplementary material.

\section{Thermodynamic properties}

Thermal properties such as thermal diffusivities, specific heat capacities etc. of octahydroquinolindiones are crucially important from the viewpoint not only of fundamental aspects for academia but also of various processing and applications of the octahydroquinolindiones. On the basis of vibrational analysis and statistical thermodynamics, the standard thermodynamic functions: heat capacity $\left(\mathrm{C}_{\mathrm{p}, \mathrm{m}}^{\circ}\right)$, entropy $\left(\mathrm{S}_{\mathrm{m}}^{\circ}\right)$ and enthalpy $\left(\mathrm{H}_{\mathrm{m}}^{\circ}\right)$ were obtained and listed in Table 3 . As observed from Table 3 , values of heat capacity, entropy and enthalpy increase with the increase of temperature from 100 to $500 \mathrm{~K}$ which is attributed to the enhancement of molecular vibration with increase in the temperature.

The correlation between these thermodynamic properties and temperatures $T$ are shown in Fig. 10. The correlation equations for octahydroquinolindiones are as follows:

$$
\begin{aligned}
& C_{\mathrm{p}, \mathrm{m}}^{\circ}=Y=1.4506+0.30045 T-4.56^{*} 10^{-5} T^{2} \quad\left(R^{2}=0.99953\right) \\
& S_{\mathrm{m}}^{\circ}=Y=60.6378+0.32287 T-3.88357^{*} 10^{-5} T^{2} \quad\left(R^{2}=0.99999\right) \\
& H_{\mathrm{m}}^{\circ}=Y=249.5756+0.00344 T+1.3922910^{-4} T^{2} \quad\left(R^{2}=0.99999\right)
\end{aligned}
$$




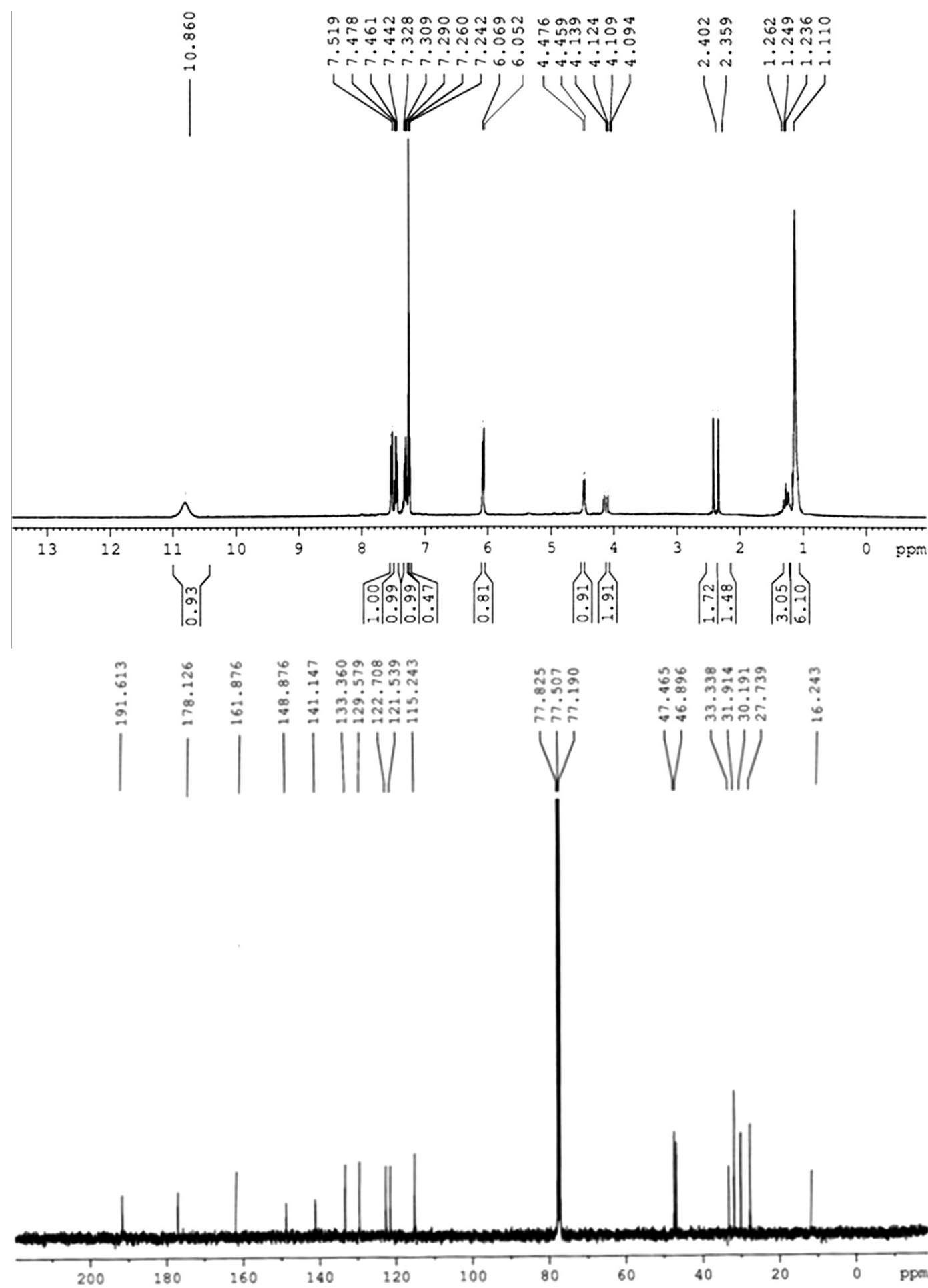

Fig. 9. ${ }^{1} \mathrm{H}$ NMR and ${ }^{13} \mathrm{C}$ NMR spectra of $2^{\prime}-\mathrm{NOHQ}$.

Table 3

Thermodynamic properties of 2'-NOHQ at different temperatures at B3LYP/6-311++G (d,p) level.

\begin{tabular}{llcc}
\hline$T(\mathrm{~K})$ & $H_{\mathrm{m}}(\mathrm{kcal} / \mathrm{mol})$ & $C_{\mathrm{p}, \mathrm{m}}(\mathrm{Cal} / \mathrm{mol} \mathrm{K})$ & $S_{\mathrm{m}}(\mathrm{Cal} / \mathrm{mol} \mathrm{K})$ \\
\hline 100 & 251.324 & 31.627 & 92.439 \\
200 & 255.818 & 58.547 & 123.897 \\
300 & 263.108 & 87.469 & 153.867 \\
400 & 273.282 & 115.523 & 183.512 \\
500 & 286.08 & 139.685 & 212.414 \\
\hline
\end{tabular}

These equations could be used for the further studies on the title compound. For instance, when the interaction of octahydroquinolindiones with any other compound is studied, these thermodynamic properties could be obtained from the above equations and then can be used to calculate the change in Gibbs free energy of the reaction, which will in turn help to judge the spontaneity of the reaction. 

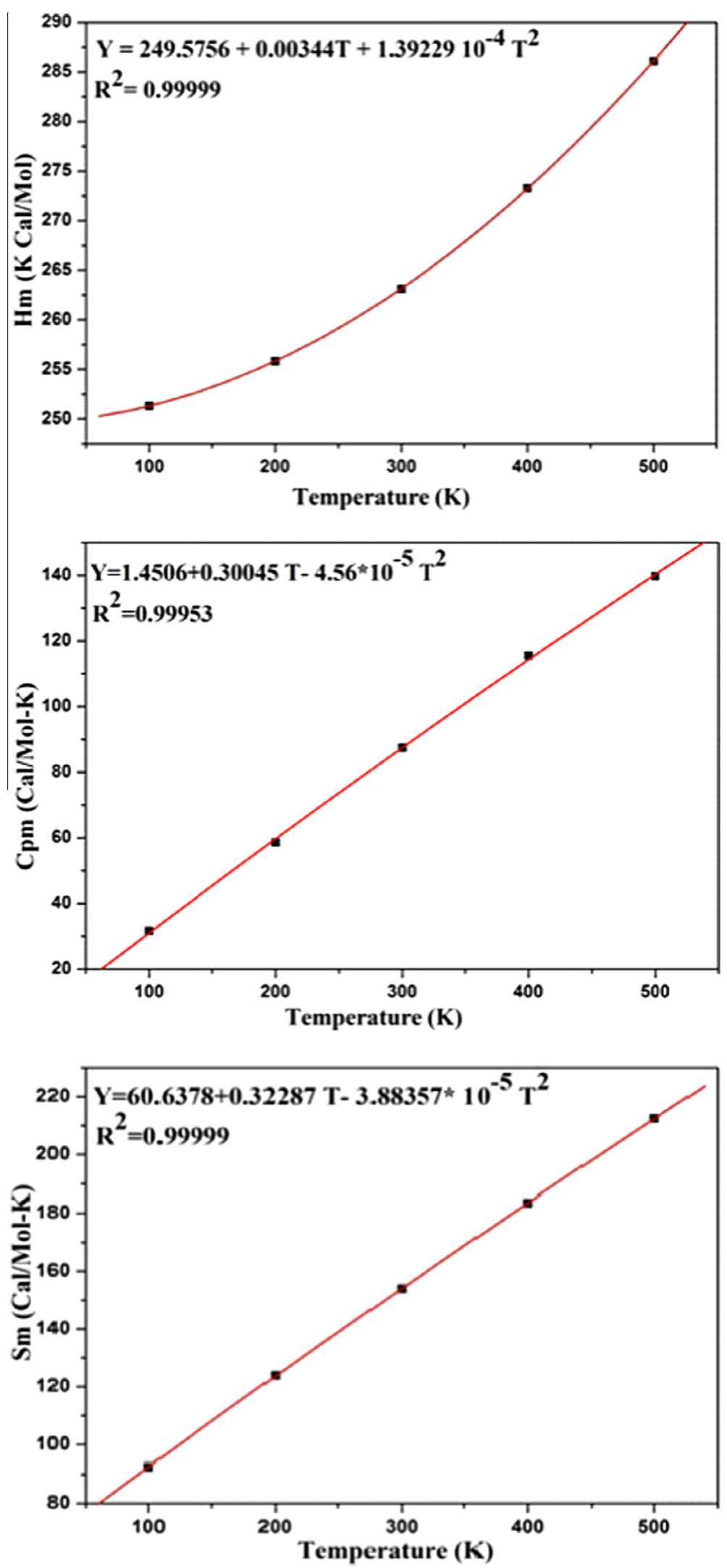

Fig. 10. Temperature dependence of the thermodynamic values $H_{\mathrm{m}}^{\circ}, \mathrm{C}_{\mathrm{p}, \mathrm{m}}^{\circ}$, and $S^{\circ} \mathrm{m}$ of $2^{\prime}-\mathrm{NOHQ}$. 


\section{Conclusions}

Vibrational, electronic, NMR, reactivity and structural aspects of $2^{\prime}$-NOHQ and its isomer $3^{\prime}$-NOHQ were studied in detail based on B3LYP/6-311++G (d,p) method, and the results were compared with the experimental results. A detailed normal coordinate analysis of all the normal modes along with PED assignment has been made indicating the composition of each normal mode. Comparison between the calculated and experimental vibrational frequencies indicate that the results are in good agreement with experimental values. The ${ }^{13} \mathrm{C}$ and ${ }^{1} \mathrm{H}$ NMR spectra of the compounds were recorded, assignment of the chemical shifts were done for calculated and experimental values. The thermodynamic properties of the title compounds at different temperatures were calculated, and the correlations between $\mathrm{C}_{\mathrm{p}, \mathrm{m}}^{\circ}, \mathrm{S}_{\mathrm{m}}^{\circ}, \mathrm{H}_{\mathrm{m}}^{\circ}$ and temperatures have also been given for both the compounds.

\section{Appendix A. Supplementary material}

Supplementary data associated with this article can be found, in the online version, at http://dx.doi.org/10.1016/j.saa.2014.09.021.

\section{References}

[1] (a) G. Claassen, E. Brin, C. Crogan-Grundy, M.T. Vaillancourt, H.Z. Zhang, S.X Cai, J. Drewe, B. Tseng, S. Kasibhatla, Cancer Lett. 274 (2009) 243-249; (b) Z.-J. Ni, P. Barsanti, N. Brammeier, A. Diebes, D.J. Poon, S. Ng, S. Pecchi, K Pfister, P.A. Renhowe, S. Ramurthy, A.S. Wagman, D.E. Bussiere, V. Le, Y. Zhou, J.M. Jansen, S. Ma, T.G. Gesner, Bioorg. Med. Chem. Lett. 16 (2006) 3121-3124.

[2] A. Afonso, J. Weinstein, M.J. Gentles, (Schering Corp.) WO 9203327, 1992.

[3] (a) R.M. Forbis, K.L. Rinehart Jr., J. Am. Chem. Soc. 95 (1973) 5003-5013; (b) H.M. Hassanin, S.M. El-edfawy, Heterocycles 85 (2012) 2421-2436.

[4] J.C. Lanter, Z. Sui, M.J. Macielag, J.J. Fiordeliso, W. Jiang, Y. Qiu, S. Bhattacharjee, P. Kraft, T.M. John, D. Haynes-Johnson, E. Craig, J. Clancy, J. Med. Chem. 47 (2004) 656-662.

[5] G. Anquetin, J. Greiner, P. Vierling, Tetrahedron 61 (2005) 8394-8404.

[6] P.D. Duarte, R.P. Severino, P.C. Vieira, D. Brömme, A.G. Corrêa, 4th Brazilian Symposium on Medicinal Chemistry, Brazilian Chemical Society (SBQ).

[7] C.T. Alabaster, A.S. Bell, S.F. Campbell, P. Ellis, C.G. Henderson, D.A. Roberts, K.S Ruddock, G.M. Samuels, M.H. Stefaniak, J. Med. Chem. 31 (1988) 2048-2056.

[8] Farhanullah, S.Y. Kim, E.-J. Yoon, E.-C. Choi, S. Kim, T. Kang, F. Samrin, S. Puri, J. Lee, Bioorg. Med. Chem. 14 (2006) 7154-7159.

[9] US 8247420 B2, US 12/124, 985, 2012.

[10] F. Domínguez-Fernandez, J. Lopez-Sanz, E. Perez-Mayoral, D. Bek, R.M. MartınAranda, A.J. Lopez-Peinado, J. Cejka, Chem. Cat. Chem. 1 (2009) 241-243.

[11] M. Marull, O. Lefebvre, M. Schlosser, Eur. J. Org. Chem. (2004) 54-63. and references cited therein.
[12] K.Y. Lee, J.N. Kim, Bull. Korean Chem. Soc. 23 (2002) 939-940.

[13] J. Ferguson, F. Zeng, N. Alwis, H. Alper, Org. Lett. 15 (2013) 1998-2001.

[14] S.H.S. Azzam, A. Siddekha, M.A. Pasha, Tetrahedron Lett. 53 (2012) 6306-6309.

[15] P. Hohenberg, W. Kohn, Phys. Rev. 136B (1964) 864-871.

[16] M.J. Frisch, G.W. Trucks, H.B. Schlegel, G.E. Scuseria, M.A. Robb, J.R. Cheeseman, J.A. Montgomery, T. Vreven, K.N. Kudin, J.C. Burant, J.M. Millam, S.S. Iyengar, J. Tomasi, V. Barone, B. Mennucci, M. Cossi, G. Scalmani, N. Rega, G.A. Petersson, H. Nakatsuji, M. Hada, M. Ehara, K. Toyota, R. Fukuda, J. Hasegawa, M. Ishida, Nakajima, Y. Honda, O. Kitao, H. Nakai, M. Klene, X. Li, J.E. Knox, H.P. Hratchian, J.B. Cross, C. Adamo, J. Jaramillo, R. Gomperts, R.E. Stratmann, O. Yazyev, A.J. Austin, R. Cammi, C. Pomelli, J.W. Ochterski, P.Y. Ayala, K. Morokuma, G.A. Voth, P. Salvadorm, J.J. Dannenberg, V.G. Zakrzewski, S. Dapprich, A.D. Daniels, M.C. Strain, O. Farkas, D.K. Malick, A.D. Rabuck, K. Raghavachari, J.B. Foresman, J.V. Ortiz, Q. Cui, A.G. Baboul, S. Clifford, J. Cioslowski, B. Stefanov, G. Liu, A. Liashenko, P. Piskorz, I. Komaromi, R.L. Martin, D.J. Fox, T. Keith, M.A. AlLaham, C.Y. Peng, A. Nanayakkara, M. Challacombe, P.M.W. Gill, B. Johnson, W. Chen, M.W. Wong, C. Gonzalez, J.A. Pople, Gaussian 03, Revision C.02, Gaussian Inc., Wallingford, CT 06492, 2003.

[17] C.T. Lee, W.T. Yang, R.G. Parr, Phys. Rev. B 37 (1988) 785-789.

[18] R.G. Parr, W. Yang, Density Functional Theory of Atoms and Molecules, Oxford University Press, New York, 1989.

[19] A.D. Becke, J. Chem. Phys. 98 (1993) 5648-5652;

G.A. Petersson, A. Bennett, T.G. Tensfeldt, M.A. Allaham, W.A. Shirley, J. Mantzaris, J. Chem. Phys. 89 (1988) 2193-2218.

[20] C. Clavaguera-Sarrio, N. Ismail, C.J. Marsden, D. Begue, C. Pouchan, Chem. Phys. 302 (2004) 1-11.

[21] S.K. Adjokatse, A.K. Mishra, U.V. Waghmare, Polymer 53 (2012) 2751-2757.

[22] P. Pulay, G. Fogarasi, F. Pang, J.E. Boggs, J. Am. Chem. Soc. 101 (1979) 25502560.

[23] G. Fogarasi, X. Zhou, P.W. Taylor, P. Pulay, J. Am. Chem. Soc. 114 (1992) 81918201.

[24] J.M.L Martin, C. Van Alsenoy, Gar2ped, University of Antwerp, 1995.

[25] G.A. Zhurko, D.A. Zhurko, Chemcraft, 2005, <http://www.chemcraftprog.com>.

[26] M.D. Halls, J. Velkovski, H.B. Schlegel, Theor. Chem. Acc. 105 (2001) 413421.

[27] S. Mishra, P. Tandon, A.P. Ayala, Spectrochim. Acta Part A 88 (2012) 116-123.

[28] A.K. Mishra, P. Tandon, J. Phys. Chem. 113 (44) (2009) 14629-14639.

[29] C. Santhosh, P.C. Misra, J. Mol. Model. 3 (1997) 172-181.

[30] G.A. Guirgis, P. Klaboe, S. Shen, D.L. Powell, A. Gruodis, V. Aleksa, C.J. Nielsen, J. Tao, C. Zheng, J.R. Durig, J. Raman Spectrosc. 34 (2003) 322-336.

[31] P.L. Polavarapu, J. Phys. Chem. 94 (1990) 8106-8112.

[32] L.J. Bellamy, The Infrared Spectra of Complex Molecules, John Wiley, New York, 1956.

[33] G. Keresztury, Raman spectroscopy: theory, in: J.M. Chalmers, P.R. Griffiths (Eds.), Handbook of Vibrational Spectroscopy, vol. 1, John Wiley \& Sons, New York, 2002

[34] L.J. Bellamy, The IR spectra of Complex Molecules, John Wiley and Sons, New York, 1975.

[35] N.P.G. Roges, A Guide to the Complete Interpretation of the Infrared Spectra of Organic Structures, Wiley, New York, 1994.

[36] R.M. Silverstein, G.C. Bassler, T.C. Morrill, Spectrometric identification of organic compounds, third ed., John Wiley \& Sons, New York, NY, 1974. p. 239.

[37] J. Mohan, Organic Spectroscopy-Principles Applications, Narosa Publishing House, New Delhi, 2001. 